Article Review

\title{
Habitat dan Kondisi Bulu Babi (Sea Urchin) di Pulau Buyu Lingga
}

\author{
Nilmawati Daeng Mangawi ${ }^{\star}$ \\ *Jurusan Manajemen Sumber Daya Perairan, Fakultas Perikanan dan IImu Kelautan, Universitas Negeri \\ Gorontalo. Email: nilmadgmangawi@gmail.com
}

\section{Introduction}

Perairan laut Indonesia memiliki keanekaragaman sumber daya hayati dan ekosistem terumbu karang yang tinggi. Hampir 85\% terumbu karang Indonesia terancam rusak dan sekitar 50\% mendapat ancaman kerusakan tinggi. Hal ini akan sangat berpotensi merusak interaksi antara komponen biotik dan abiotik. Salah satu dari komponen biotik tersebut adalah makrozobentos (Ghufran \& Koordi, 2010). Perairan Pulau Buyu merupakan perairan laut yang masuk ke dalam kawasan Desa Rejai, Kabupaten Lingga yang merupakan suatu area lokasi yang lengkap yang memiliki ekosistem lamun, terumbu karang serta mangrove yang saling berdampingan. Perairan ini menyimpan potensi keanekaragaman biota yang cukup tinggi, meliputi sumber daya ikan, krustasea, moluska, serta biota Echinodermata. Salah satu Echinodermata penghuni terumbu karang adalah Echinotrix diadema (Nane et al., 2020). Selain itu, habitat alami terumbu karang ini merupakan wilayah yang dimanfaatkan oleh beragam biota sebagai kawasan perlindungan diri dan rumah bagi ancaman pemangsa dalam rantai makanan pada ekosistem laut serta berperan sebagai rumah untuk regenerasi dan perkembangbiakan organisme akuatik sehingga dapat bereproduksi. Sehingga habitat berperan penting sebagai fungsinya untuk penunjang keberadaan populasi biota, (Wulandewi, 2015).

Bulu babi atau Echinoidea merupakan jenis biota perairan yang berasal dari filum Echinodermata yang dimanfaatkan oleh masyarakat di Pulau Buyu. Bulu Babi ini merupakan biota yang dapat dikonsumsi (Nane, 2019a) dan dimanfaatkan gonadnya untuk tujuan ekonomi (Nane, 2019b). Karena bulu babi merupakan salah satu biota laut bernilai ekonomis bahkan di Wakatobi, telah diperjual belikan secara lokal (Nane, 2019c). Sementara itu, masyarakat Pulau Buyu sehingga dari waktu ke waktu eksploitasi dari Echinoidea ini mengalami peningkatan, (Ningsih 2015). Studi mengenai berbagai aspek biologi bulu babi telah dilakukan di berbagai tempat meliputi studi mikrohabitatnya. Keberadaan bulu babi di kawasan padang lamun berkaitan erat dengan aktivitas makannya sebagai grazer utama pada daerah padang lamun, (Agustia 2016). Kepadatan jenis adalah 
jumlah individu persatuan luas. Kepadatan masing-masing jenis pada setiap stasiun dihitung dengan, menggunakan rumus Odum (Anwar, 2015).

Aktivitas antibakteri ditemukan pada bagian tubuh yang berbeda dari green sea urchin dengan menggunakan bakteri uji. Hasil ini menunjukkan bahwa filum Echinodermata salah satunya bulu babi memiliki potensi sebagai antimikroba alami (Haug et al., 2002; Uma \& Parvathavarthini, 2010). Metabolit yang dihasilkan oleh bulu babi dapat dimanfaatkan da-lam bidang pengobatan yang berpotensi untuk dimanfaatkan sebagai antibiotik tipe baru ka-rena mengandung senyawa bioaktif (Abubakar et al., 2012). Sebuah studi melaporkan 43\% aktivitas antimikroba berasal dari 83 spesies dari filum Echinodermata yang tidak diidentifikasi yang diperoleh dari pantai barat daya California dan Teluk California menunjukkan adanya aktivitas antimikroba, kemudian sebesar 58\% dari 36 spesies yang tidak diidentifikasi dari Laut Karibia juga menunjukkan adanya aktivitas antimikroba (Li et al., 2010).

Bulu babi memiliki cangkang yang keras, 95\% bagian tubuh bulu babi didominasi oleh duriduri yang sangat rapuh. Duri ini digunakan untuk bergerak, melindungi diri, serta mencapit makanan, dan untuk jenis-jenis ter-tentu mengandung racun. Toksin yang dihasilkan bulu babi dapat dimanfaatkan dalam bidang pengobatan yang berpotensi sebagai antibiotik (Abubakar et al., 2012). Echinodermata merupakan salah satu biota yang berasosiasi kuat dengan ekosistem padang lamun dan berperan dalam siklus rantai makanan di ekosistem tersebut. Tingginya tutupan vegetasi lamun di perairan memungkinkan kehadiran berbagai biota yang berasosiasi dengan ekosistem padang lamun termasuk bulu babi untuk mencari makan, tempat hidup, memijah dan tempat berlindung untuk menghindari predator (Supono \& Arbi, 2010).

Zakaria (2013) menyatakan bahwa bulu babi jenis D. setosum suka hidup mengelompok dan sering berada di perairan sedikit terbuka. Mustaqim dkk. (2013) yang menyatakan bahwa bulu babi jenis E. calamaris dapat ditemukan pada daerah rataan terumbu karang dan daerah tubir. Hasil penelitian yang dilakukan oleh Wulandewi (2015), menyatakan bahwa pada sebaran jenis bulu babi secara vertikal sebagian besar dari famili Diadematidae. Habitat dan sebaran bulu babi berada pada pola sebaran terumbu karang dan lamun. Menurut Sumadhiharga (2006), stasiun monitoring berada dalam atau berdekatan dengan desa yang telah ditentukan. Menetukan posisi stasiun transek permanen menggunakan GPS (Global Positioning Systems), sehingga lokasinya dapat ditemukan kembali, dipantau untuk penelitian lanjutan mengenai bulu babi

Menurut Nystrom et al. (2000) dalam Setyawan dkk. (2014) bulu babi merupakan salah satu spesies kunci bagi komunitas terumbu karang. Hal ini karena bulu babi adalah salah satu pengendali populasi mikroalga. Keberadaan bulu babi pada suatu ekosistem tidak lepas juga dari pengaruh faktor fisika kimia pada lingkungan tersebut. Bulu babi memiliki fisik pertahanan (duri) dan 
yang membuat mereka cocok untuk bertahan dan melindungi diri dari organisme laut seperti moluska, udang, kepiting, polychaetes (cacing anelida), copepods (crustacea kecil), dan ikan, (Ayyagari dan Kondamudi, 2014).

Nane, (2019d) melaporkan telur bulu babi dapat di konsumsi. Bahkan dibeberapa daerah, misalnya di Kepulauan Wakatobi. Pemanfaatan bulu babi telah mengalami overfishing (Nane \& Paramata, 2020). Menurut (Masdudin, 2010) landak laut/bulu babi berbentuk bundar dan tidak berlengan, hewan ini memiiliki duri yang cukup tajam yang dapat digerakkan. Landak laut biasanya hidup dibeberapa daerah seperti pantai, batu karang, dasar laut dan dalam lumpur, sumur-sumuran daerah pantai, muara sungai dan lain-lain. Menurut Haerul (2011), Diadema setosum cenderung menyukai lamun Enhalus acoroides, sedangkan bulu babi Tripneustes gratilla, Mespilia globulus dan Echinothrix calamaris cenderung lebih menyukai Halodule uninervis

Selain itu, Diadema setosum merupakan spesies kunci dalam ekosistem perairan dan secara ekologis berperan dalam komunitas lamun (Salmanu, 2010). McAlister dan Moran (2012) menyatakan bahwa ada 2 jenis sumber bahan makanan bulu babi yaitu nonplanktonik yang bukan berasal dari plankton tapi berasal dari kuning telur induknya dan planktotrofik yang berasal dari fitoplankton maupun zooplankton Tjendanawangi, (2010) menjelaskan bobot tubuh bulu babi yang ditangkap di alam berkaitan dengan tipe substrat di habitatnya. Tipe substrat yang didominasi kan campuran pasir berlumpur dan pecahan karang dan ditumbuhi oleh lamun yang pendek dengan kerapatan lamun yang tidak padat, biasanya memperlihatkan bobot tubuh yang lebih kecil.

Kelimpahan jenis bulu babi terendah dari jenis T. pileolus karena hanya ditemukan 2 individu. Hal ini diduga karena keberadaan T. pileolus menyukai hidup menyendiri dan hidup pada habitat dengan substrat gabungan antara terumbu karang dan lamun. Di samping itu, diduga adanya faktor fisik tertentu yang menjadi pembatas meskipun faktor lingkungan secara umum berada pada kisaran optimum untuk kehidupan jenis bulu babi yang lain. Rendahnya kelimpahan S. bicolor dan T. gratilla pada stasiun I yang merupakan jenis bulu babi yang sangat menyukai habitat lamun diduga erat kaitannya dengan aktivitas masyarakat setempat dalam memanfaatkan bulu babi secara berlebihan untuk keperluan ekonomi karena kedua jenis bulu babi ini mudah diambil dan tidak membahayakan seperti halnya Diadema setosum (Laning, 2014).

Pengamatan morfologi bulu babi ini dilakukan dengan menggunting duri bulu babi menggunakan gunting, kemudian melakukan pembedahan secara horizontal menggunakan gergaji besi, setelah itu dilakukan pengamatan bagian organ dalam tubuh bulu babi. Cara pembedahan bulu babi ini mengacu pada bahan ajar "Avertebrata Air", Swignyo et al. (2005). Pernyebaran Bulu babi (Echinoidea) sangat tergantung kepada perkembangan faktor subtrat dan makanan, dapat ditemui dari daerah intertidal (pasang surut) sampai kedalaman $10 \mathrm{~m}$ (Aziz, 2011). Gonad bulu babi 
(Echinoidea) merupakan salah satu sumber daya perikanan yang telah lama dimanfaatkan oleh masyarakat pesisir sebagai bahan makanan.

Menurut Tupan dan Silaban (2017) perbedaan kadar protein dikarenakan tingkat kematangan gonad, di mana gonad yang berukuran besar dan berwana kuning secara proporsional mengandung protein yang lebih banyak. Jenis bulu babi Diadema savignyi terletak pada ciri utamanya duri-duri panjang dan lancip dibandingkan dengan jenis lain, duri-duri jenis bulu babi Diadema paling panjang. Menurut Rumahlatu (2012), bahwa Diadema savignyi atau Astropiga radiate seluruh tubuhnya serta duri-durinya berwarna hitam, biasanya dijumpai cincin putih dan ungu yang mencolok di sekitar duburnya. Durinya panjang mencapai $10 \mathrm{~cm}$ atau lebih lancip bagai jarum dan sangat rapuh. Menurut Purwandatama dan Suryanti (2014), dapat diketahui bulu babi Astropyga radiate memiliki bentuk cangkang memipih, memiliki duri yang tebal panjang, berwarna hitam dan putih polos serta memiliki bentuk tubuh bulat putih. Menurut Tamrin dkk. (2011) mengatakan kepadatan bulu babi Diadema setosum berbanding terbalik dengan kondisi terumbu karang, dimana pada daerah kondisi terumbu karang rendah maka kepadatan bulu babi Diadema setosum tinggi, dan begitu juga sebaliknya, bila kondisi terumbu karang tinggi maka kepadatan bulu babi Deadema setosum rendah.

Pengamatan anatomi pada bulu babi dilakukan dengan cara melakukan pembedahan menggunakan gergaji besi, setelah itu dilakukan pengamatan bagian organ dalam tubuh bulu babi. Cara pembedahan bulu babi ini mengacu pada Irawan (2012) dalam Suyanti (2013) Persebaran Bulu babi (Echinoidea) sangat tergantung kepada perkembangan faktor substrat dan makanan, dapat ditemui dari daerah intertidal (pasang surut) sampai kedalaman 10 m (Aziz, 2011). Diketahui bahwa kelimpahan jenis bulu babi Diadema savignyi adalah sebesar 83 ind/ha dan pada jenis Astropiga radiate lebih rendah yakni 45 ind/ha. Bulu Babi yang diperoleh di Pulau Buyu tergolong rendah jika dibandingkan dengan hasil penelitian (Triana et al., 2015), yakni pada kisaran 160-2230 ind/ha. Namun menurut Yusron (2012), kelimpahan bulu babi umumnya berkisar antara 100-400 ind/ha. Kondisi bulu babi di perairan Pulau Buyu tergolong sedikit dengan kelimpahan yang kecil dipengaruhi oleh adanya pengeboman, potasium, ketidaksesuaian kondisi perairan seperti salinitas yang terlalu rendah meskipun parameter perairan yang lain sudah cukup baik.

Penentuan stasiun pengamatan bulu babi dilakukan berdasarkan teknik purposive sampling. Di mana berdasarkan pertimbangan dan tujuan tertentu Fachrul (2007). Penelitian Akerina et al. (2015), berat total bulu babi Diadema savignyi rata-rata beratnya adalah 61,0 g dengan persentase masing-masing yakni duri 17,37\%, cangkang 46,72\%, gonad 8,03\%,dan bagian lainnya 16,88\%. Mengacu pada hasil penelitian Aprilia et al. (2012), bahwa bagian bulu babi yang paling berat adalah bagian cangkang. Berat sampel kering cangkang laut mencapai sebesar 90 gr. Jika 
dibandingkan dengan hasil penelitian yang dilakukan, berat cangkang yang diperoleh tergolong kecil mungkin saja dipengaruhi oleh ukuran bulu babi yang diambil Hasil penelitian (Qin et al., 2011) menunjukkan bahwa kandungan pigmen pada bulu babi Strongylocentrotus nudus berpotensi sebagai antioksidan karena mengandung napthoquinone dengan gugus spinochrome $B, E$ dan $D$

\section{Conclusion}

Hewan bulu babi (echinoidea) yang ditemui pada lokasi penelitian terdapat 2 spesies bulu babi yakni jenis Diadema savignyi dan Astropiga radiate. Jenis bulu babi Diadema savignyi dan jenis Astropiga radiate masing-masing dijumpai pada 2 tipe habitat yakni pasir berkarang dan pasir berbatu. Morfologi bulu babi Diadema savignyi dan Astropiga radiate dari hasil pengamatan di laboraturium dikatakan berbeda dari bentuk duri, warna dan ujung duri. Nilai kelimpahan jenis bulu babi Diadema savignyi dan Astropiga radiate tergolong rendah. Bulu babi yang ada di perairan laut Teluk Dalam menunjukan kondisi yang berfariasi dimana terdapat 4 jenis bulu babi yaitu Diadema savignyi, Diadema setosum, Echinotrix calamaris, dan Astropiga radiate. Morfologi dari bulu yang ditemukan mempunyai bentuk tubuh memipih, untuk warna tubuh Diadema setosum berwarna hitam dan memiliki duri yang runcing berwarna hitam, Diadema savignyi memiliki tubuh hitam namun memiliki garis berwarna biru terang dan duri yang runcing berwarna putih kehitaman, untuk bentuk tubuh Astropyga radiate tubuh berwarna putih dan duri pendek berwarna hitam dan putih dan Echinotrix calamaris memiliki tubuh berwarna hitam sedangkan duri berwarna merah dan putih. Anatomi dari keempat jenis bulu babi (Deadema setosum, Deadema savignyi, Astropyga radiate, Echinotrix calamaris) mempunyai anatomi yang sama yaitu gigi, tembolok, usus, lambung, telur, ampullae. Kelimpahan bulu babi di perairan laut Teluk Dalam menunjukkan kepadatan terendah 160 Ind/ha hingga yang paling tinggi 2230 Ind/ha dengan ( $\left.\mathrm{H}^{\prime}\right)$ indeks Keanekaragaman ( $\left.\mathrm{H}^{\prime}\right)$ bulu babi yaitu 1,46 dalam katagori sedang. Nilai indeks Keseragaman (E) bulu babi diperoleh nilai 0,7 yaitu masuk dalam katagori tinggi. Nilai indeks Dominasi bulu babi termasuk dalam katagori tidak stabil 0,45. Nilai parameter perairan yang diperoleh di perairan laut Teluk Dalam yaitu suhu berkisar 29,6-31,70C, salinitas berkisar 35,4-38,6\%, kedalaman 4-5 meter, kekeruhan 1,06-1,69 NTU, derajat keasaman 7,50-8,34 dan oksigen terlarut 7,3-7,8 mg/L. Kondisi parameter perairan tersebut masih tergolong layak bagi kehidupan bulu babi di perairan laut Teluk Dalam. Hasil analisa kandungan gizi bulu babi Diadema setosum dan Echinotrix calamaris Tanjung Metiella, dapat dimanfaatkan sebagai sumber makanan pengganti ikan dan parameter lingkungan mendukung pertumbuhan bulu babi. Perlu adanya penelitian lanjutan terhadap bulu babi jenis Tripneustes gratilla dan Echinometra mathaei 
pada musim barat agar dapat dijadikan data pembanding dan penelitian tentang reproduksi dan dinamika populasi bulu babi di Tanjung Metiella. Hasil penelitian di zona sublitoral perairan Iboih Kecamatan Sukakarya Kota Sabang ditemukan 6 spesies Echinoidea dari 2 famili, yaitu: Diadema setosum, Diadema savignyi, Echinothrix diadema, Echinothrix calamaris, Centrostephanus rodgersii, dan Echinometra mathaei. Struktur komunitas bulu babi (Echinoidea) di kawasan ini tergolong baik, dengan indeks keanekaragaman $H^{\prime}=1,345$, Indeks keseragaman tergolong cukup merata dengan nilai indeks $E=0,75$, dan Indeks dominansi tergolong rendah/tidak ada jenis yang mendominansi dengan nilai indeks $D=0,35$. Bulu babi yang ditemukan di kawasan padang lamun Pantai Merta Segara, Sanur terdiri dari 9 spesies dari 5 famili, yaitu Diadema savignyi, Diadema setosum, Diadema palmeri, Echinothrix calamaris, Echinometra mathei, Echinocardium sp., Mespilia globulus, Tripneustues gratilla dan Toxopneustes sp. Populasi bulu babi di Pantai Merta Segara, Sanur, termasuk dalam keadaan sedang $\left(H^{\prime}=1-3\right)$, penyebaran merata $(E=0,76)$ dan dominansi rendah $(0$, 25). Kepadatan dan jumlah jenis bulu babi dipengaruhi oleh keberadaan aktivitas masyarakat dan tipe substrat pasir halus sebagai habitatnya

\section{References}

Abubakar, L., Wangi, C., Uku, J. \& Ndirangu, S. (2012). Antimicrobial Activity of Vari-ous Extracts of The Sea Urchin Trip-neustes gratilla (Echinoidea). African Journal of Pharmacology and Therapeutics, 1(1), 19- 23. http://journals.uonbi.ac.ke/ajpt/article/view/1076

Akerina.F.O, Nurhayati. T, dan Ruddy S. (2015). Isolasi dan Karakterisasi Senyawa Antibakteri dari Bulu Babi. Jurnal JPHPI. 18 (1):61-72. http://repository.ipb.ac.id/handle/123456789/77508

Anwar. C, Muzahar, dan Karlina. I. (2015). Bioekologi Bulu babi (Echinoidea) di Perairan Laut Teluk Dalam Desa Malang Rapat Kecamatan Gunung Kijang Kabupaten Bintan. Jurnal penelitian. Programme Study of Marine Science Marine Science and Fisheries Faculty, Maritime Raja Ali Haji University, Tanjungpinang. 1-9.

Aprillia HA, Delianis P, Ervia Y. (2012). Uji toksisitas ekstrak kloroform cangkang dan duri landak laut (Diadema setosum) terhadap mortalitas Nauplius Artemia sp. Jurnal of Marine Research 1(1), 75-83. https://doi.org/10.14710/jmr.v1i1.890

Ayyagari, A, and Kondamundi, R, B. (2014). Ecological Significance of the Association between stomopneustes Variolaris (Echinoidea) and Lumbrinerislatreilli (polychaeta) from Visakhapatnam Coast India. Jurnal of Marine Biologi. India. https://www.hindawi.com/journals/jmb/2014/640785/ 
Aziz, A. (2011). “Beberapa Catatan Tentang Perikanan Bulu Babi”. Jurnal Oseana, Vol. 18, No. 2, Tahun 2011. http://oseanografi.lipi.go.id/dokumen/oseana_xviii(2)65-75.pdf

Fachrul, M, F, (2007). Metode Sampling Bioekologi. Bumi Aksara : Jakarta

Ghufran, M. dan Koordi, K. (2010). Ekosistem Terumbu Karang. Rineka Cipta, Jakarta.

Haerul, A. (2011). Daya Grazing dan Preferensi Makanan Bulu Babi Terhadap Berbagai Jenis Lamun di Perairan Pulau Barrang Lompo, Sulawesi Selatan. Prosiding Pertemuan IImiah Nasional Tahunan VIII ISOI 2011.

Laning TH, Deny SY dan Joko W. (2014). Sebaran Bulu Babi (Echinoidea) di Kawasan Padang Lamun Pantai Mertasegara, Sanur Bali. Jurnal Biologi. 18(2), 41-45. https://ojs.unud.ac.id/index.php/BIO/article/view/16834

Li, C., Haug, T., Stensvåg, K. (2010). Antimi-crobial Peptides in Echinoderms. Invertebrate Survival Journal, 132-140. http://www.isj.unimore.it/index.php/ISJ/article/view/214

McAlister,J . S.,\& Moran,A. L., (2012). Relationships among Egg Size, Composition, and Energy: a Comparative Study of Geminate Sea Urchins. Journal of Plos one,7(7), 1-9. https://journals. plos.org/plosone/article?id=10.1371/journal.pone.0041599

Mustaqim, M. M. (2013). Kelimpahan Jenis Bulu Babi (Echinoidea, Leske 1778) Di Rataan Dan Tubir Terumbu Karang Di Perairan Si Jago-Jago, Tapanuli Tengah. Management of Aquatic Resources Journal, 2(4), 61-70 . https://ejoumal3.undip.ac.id/indexphp/maquares/article/view/4269/4132

Nane, L. (2019a). Efisiensi Mesin Teknologi Sapurata Dalam Mengoptimalisasi Produksi Inovasi Pangan Kukure Di Pulau Barrang Lompo, Makassar. https://doi.org/10.31230/osf.io/q8spg

Nane, L. (2019b). Impact of overfishing on density and test-diameter size of the sea urchin Tripneustes gratilla at Wakatobi Archipelago, south-eastern Sulawesi, Indonesia. BioRxiv, 727271. https://www.biorxiv.org/content/10.1101/727271v1

Nane, L., \& Paramata, A. R. (2020). Impact of Overfishing on Density and Test-Diameter Size of the Sea Urchin Tripneustes gratilla at Wakatobi Archipelago, South-Eastern Sulawesi, Indonesia. ILMU KELAUTAN: Indonesian Journal of Marine Sciences, 25(2), 53-56. https://doi.org/10.14710/ik.ijms.25.2.53-56

Nane, L. (2020). Pemanfaatan Telur Landak Laut Diadema setosum di Pulau Taliabu, Maluku Utara, Indonesia. https://doi.org/10.31219/osf.io/kmtuv

Nane, L. (2019c). Sea Urchin Sustainability Studies Based on Dimension Biology, Ecology and Technology at Around of Tolandono Island and Sawa Island at Wakatobi Conservation Area. https://doi.org/10.31230/osf.io/4whz6 
Nane, L. (2019d). Studi Keberlanjutan Perikanan Landak Laut Berdasarkan Dimensi Biologi, Ekologi Dan Teknologi Di Sekitar Pulau Tolandono Dan Pulausawa Kawasan Konservasi Wakatobi [Skripsi, Universitas Hasanuddin]. https://Marxiv.Org/9zdvr/

Nane, L., Baruadi, A. S. R., \& Mardin, H. (2020). The density of the blue-black urchin Echinotrix diadema (Linnaeus, 1758) in TominiBay, Indonesia. Tomini Journal of Aquatic Science, 1(1), 16-21. https://doi.org/10.37905/tjas.v1i1.5939

Ningsih. R. W. (2015). Studi Keanekaragaman Teripang (Holothuridae) Dan Bulu babi (Echinoidae) Di Perairan Pantai Desa Sungai Bakau Kecamatan Kumai Kabupaten Kotawaringin Barat. Skripsi. Institut Agama Islam Negeri (lain) Palangka Raya. http://digilib.iainpalangkaraya.ac.id/183/

Purwandatama, R., Suryanti, -., \& Ain, C. (2013). Kelimpahan Bulu Babi (Sea Urchin) Pada Karang Massive Dan Branching Di Daerah Rataan Dan Tubir Di Legon Boyo, Pulau Karimunjawa, Taman Nasional Karimunjawa. Management of Aquatic Resources Journal (MAQUARES), 3(1), 17-26. https://ejournal3.undip.ac.id/index.php/maquares/article/view/4282

Purwaningsih, S. (2012). Aktivitas Antioksidan dan Komposisi Kimia Keong Matah Merah (Cerithidea obtusa) (Antioxidant Activity and Nutrient Composition of Matah Merah Snail (Cerithidea obtusa)). ILMU KELAUTAN: Indonesian Journal of Marine Sciences, 17(1), 39-48. https://doi.org/10.14710/ik.ijms.17.1.39-48

Qin, L., Zhu, B. W., Zhou, D. Y., Wu, H. T., Tan, H., Yang, J. F., ... \& Murata, Y. (2011). Preparation and antioxidant activity of enzymatic hydrolysates from purple sea urchin (Strongylocentrotus nudus) gonad. LWT-Food Science and Technology, 44(4), 1113-1118. https://doi.org/10.1016/j.Iwt.2010.10.013

Rumahlatu, D. (2013). Aktivitas Makan dan Pertumbuhan Bulu Babi Deadema setosum Akibat Paparan Logam Berat Kadmium (Feeding Activity and Growth Sea Urchins Deadema setosum Due to Heavy Metal Cadmium Exposure). ILMU KELAUTAN: Indonesian Journal of Marine Sciences, 17(4), 183-189. https://doi.org/10.14710/ik.ijms.17.4.183-189

Salmanu, S. (2010). Keanekaragaman dan Pola Asosiasi Gastropoda Di Padang Lamun (Seagrass) Sebagai Sarana Penunjang Pembelajaran Mata Kuliah Ekologi Laut [Tesis]. Program Pascasarjana Universitas Negeri Malang, Malang.

Suharsono, Sumadhiharga,O,K. (2014). Panduan Monitoring Kesehatan Terumbu karang Ikan Karang Megabenthos dan Penulisan Laporan. Lembaga IImu Pengetahuan Indonesia. COREMAP-CTI Supono dan U.Y. Arbi. (2010). Jenis-jenis Ekinodermata di Padang Lamun Perairan Kema, Sulawesi Utara. Oseanologi dan Limnologi di Indonesia, 36(3), 329-341. 
Suwignyo, S., Widigdo, B., Wardianto, Y. (2005). Avertebrata Air (Jilid 1). Penebar Swadaya. Jakarta. $208 \mathrm{hlm}$.

Thamrin, Y.J. Setiawan dan S.H. Siregar. (2011). Analisis Kepadatan Bulu Babi Diadema setosum pada Kondisi Terumbu Karang Berbeda di Desa Mapur Kepulauan Riau. Jurnal IImu Lingkungan, 5(1), 45-53. https://jil.ejournal.unri.ac.id/index.php/JIL/article/view/349

Tjendanawangi, A. (2010). Kinerja perkembangan gonad bulu babi tripneustes gratilla yang diberi pakan buatan dengan kadar protein dan rasio energi protein berbeda serta hormon estradiol17ß. [Thesis]. Institut Pertanian Bogor. http://repository.ipb.ac.id/handle/123456789/55049

Triana, R., Elfidasari, D,. Vimono, I.B. (2015). Identifikasi Echinodermata di selatan Pulau Tikus, Gugusan Pulau Pari, Kepulauan Seribu, Jakarta. Seminar Nasional Masyarakat Biodiversitas Indonesia, 1(3) 455-459. https://doi.org/10.13057/psnmbi/m010313

Tupan, J., \& br Silaban, B. (2017). Karakteristik Fisik-Kimia Bulu babi Diadema setosum dari beberapa Perairan Pulau Ambon. TRITON: Jurnal Manajemen Sumberdaya Perairan, 13(2), 71-78. https://ojs3.unpatti.ac.id/index.php/triton/article/view/786

Uma, B. \& Parvathavarthini, R. (2010). Anti-bacterial Effect of Hexane Extract of Sea Urchin. International Journal of Pharm-Tech Research, 2(3), 1677-1680

Wulandewi, N. (2015). Jenis dan Densitas Bulu Babi (Echinoidea) di Kawasan Pantai Sanur dan Serangan Denpasar- Bali. Jurnal Simbiosis, 3 (1): 269-280. https://ojs.unud.ac.id/index.php/simbiosis/article/view/14406

Zakaria, I.J. (2013). Komunitas Bulu Babi (Echinoidea) di Pulau Cingkuak, Pulau Sikuai dan Pulau Setan Sumatera Barat. Prosiding SEMIRATA FMIPA Universitas Lampung. Lampung. https://jurnal.fmipa.unila.ac.id/semirata/article/view/681 